\title{
Vital Signs: Deficiencies in Environmental Control Identified in Outbreaks of Legionnaires' Disease — North America, 2000-2014
}

Laurel E. Garrison, MPH${ }^{1}$; Jasen M. Kunz, MPH${ }^{2}$; Laura A. Cooley, MD ${ }^{1}$; Matthew R. Moore, MD ${ }^{1}$; Claressa Lucas, PhD ${ }^{1}$; Stephanie Schrag, DPhil ${ }^{1}$; John Sarisky, MPH ${ }^{2}$; Cynthia G. Whitney, MD ${ }^{1}$

On June 7, 2016, this report was posted as an MMWR Early Release on the MMWR website (http://www.cdc.gov/mmwr).

\section{Abstract}

Background: The number of reported cases of Legionnaires' disease, a severe pneumonia caused by the bacterium Legionella, is increasing in the United States. During 2000-2014, the rate of reported legionellosis cases increased from 0.42 to 1.62 per 100,000 persons; $4 \%$ of reported cases were outbreak-associated. Legionella is transmitted through aerosolization of contaminated water. A new industry standard for prevention of Legionella growth and transmission in water systems in buildings was published in 2015. CDC investigated outbreaks of Legionnaires' disease to identify gaps in building water system maintenance and guide prevention efforts.

Methods: Information from summaries of CDC Legionnaires' disease outbreak investigations during 2000-2014 was systematically abstracted, and water system maintenance deficiencies from land-based investigations were categorized as process failures, human errors, equipment failures, or unmanaged external changes.

Results: During 2000-2014, CDC participated in 38 field investigations of Legionnaires' disease. Among 27 landbased outbreaks, the median number of cases was 10 (range $=3-82$ ) and median outbreak case fatality rate was $7 \%$ (range $=0 \%-80 \%)$. Sufficient information to evaluate maintenance deficiencies was available for $23(85 \%)$ investigations. Of these, all had at least one deficiency; 11 (48\%) had deficiencies in $\geq 2$ categories. Fifteen cases $(65 \%)$ were linked to process failures, $12(52 \%)$ to human errors, eight (35\%) to equipment failures, and eight (35\%) to unmanaged external changes.

Conclusions and Implications for Public Health Practice: Multiple common preventable maintenance deficiencies were identified in association with disease outbreaks, highlighting the importance of comprehensive water management programs for water systems in buildings. Properly implemented programs, as described in the new industry standard, could reduce Legionella growth and transmission, preventing Legionnaires' disease outbreaks and reducing disease.

\section{Introduction}

Legionnaires' disease, a severe, sometimes fatal pneumonia, can occur in persons who inhale aerosolized droplets of water contaminated with the bacterium Legionella. Exposure to Legionella in freshwater environments such as lakes and streams does not lead to disease; however, in manmade water systems, Legionella can grow and spread to susceptible hosts, including persons aged $\geq 50$ years, smokers, and persons with underlying medical conditions such as chronic lung disease or immunosuppression.

CDC investigated the first outbreak of Legionnaires disease in 1976. Currently, approximately 5,000 cases of Legionnaires' disease are reported to CDC each year; however, Legionnaires' disease might be underdiagnosed. During 2000-2014, the rate of reported cases of legionellosis, which comprises both Legionnaires' disease and Pontiac fever, a milder, self-limited, influenza-like illness, increased $286 \%$, from 0.42 to 1.62 cases per 100,000 persons in the United States $(1,2)$ (Figure 1). The reason for this increase is unknown but is likely multifactorial. The higher rates could represent a true increase in the frequency of disease related to several factors, such as a greater number of persons at risk for legionellosis because of underlying illness or immunocompromising medications, an aging U.S. population, aging plumbing infrastructure, or changes in the climate. Increased use of diagnostic testing because of greater awareness among clinicians and availability of diagnostic tests, as well as more reliable reporting to local and state health departments and CDC could also be playing a role. Approximately $9 \%$ of cases are fatal (3). Among 32 potable water-associated outbreaks reported in the United States during 2011-2012, legionellosis was implicated in 21 (66\%) outbreaks and all 14 deaths (4). During 2000-2012, CDC's Waterborne Disease and Outbreak Surveillance System received reports of approximately 160 legionellosis outbreaks (5). 


\section{Key Points}

- Legionnaires' disease is a lung infection that is fatal for about one in 10 persons who become infected. Legionella, the bacterium that causes Legionnaires' disease, grows well in warm water, but can be killed by disinfectants, such as chlorine. Persons can get Legionnaires' disease when they breathe in small droplets of water contaminated with Legionella.

- Persons most likely to get Legionnaires' disease are those aged $\geq 50$ years, smokers, and persons with underlying medical conditions, such as chronic lung disease or weakened immune systems.

- Legionella grows best in building water systems that are not well maintained, especially where levels of chlorine or other disinfectants are low and water temperatures are optimal for its growth. Legionnaires' disease outbreaks most often occur in hotels, long-term care facilities, and hospitals. The most common sources are potable water (e.g., drinkable water used for showering), cooling towers, hot tubs, and decorative fountains.

- The key to preventing outbreaks is good management of building water systems, according to new industry standards. Outbreaks have occurred because of process failures (65\%), human errors (52\%), equipment failures $(35 \%)$, external conditions (35\%), or a combination of these $(48 \%)$. Building owners and managers should determine if their building water systems are at increased risk for Legionella growth and spread. If so, they should develop and use a Legionella water management program according to the new industry standards (http://www. cdc.gov/legionella/WMPtoolkit).

- Additional information is available at http://www.cdc. gov/vitalsigns.

Legionnaires' disease outbreak investigations require an environmental assessment to identify potential sources of exposure. Environmental assessments are rarely conducted for Legionnaires' disease cases that are not recognized as part of an outbreak; therefore, most of what is known about Legionella transmission has been learned from outbreak investigations. During 2005-2009, only 4\% of confirmed legionellosis cases reported among U.S. residents were associated with a known outbreak or cluster (G), although some sporadic cases were likely associated with unrecognized outbreaks or clusters. Identified outbreaks generally are linked to environmental
FIGURE 1. Reported cases of legionellosis per 100,000 population, by year — United States, 2000-2014

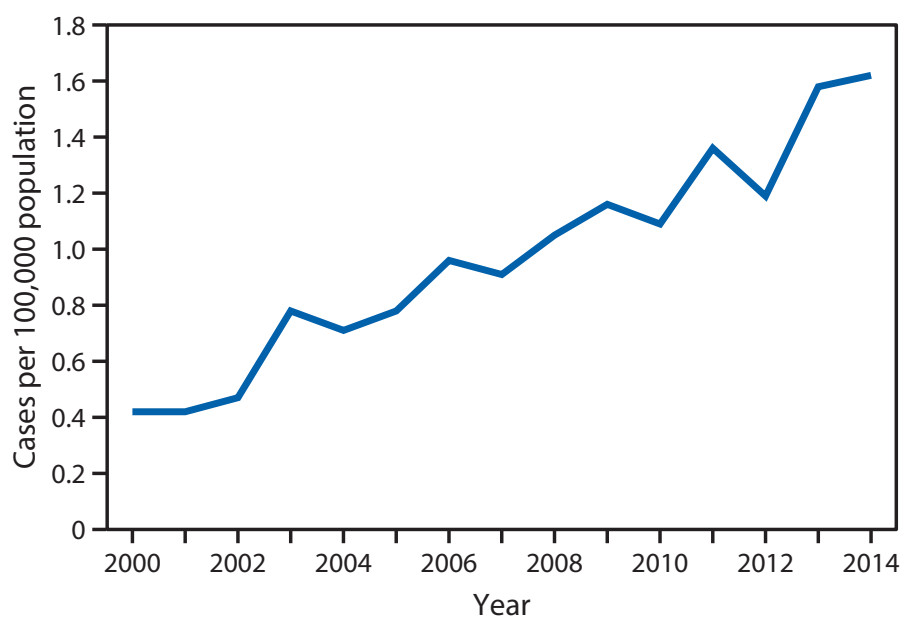

reservoirs in large or complex water systems, ${ }^{*}$ such as those found in hotels or resorts, hospitals, long-term care facilities, and cruise ships. Transmission from these water systems to humans requires aerosol generation, as can occur from showerheads, cooling towers, hot tubs, and decorative fountains ( 7 ). Only one case of possible person-to-person transmission has been reported (8). Legionnaires' disease is typically diagnosed by a Legionella urinary antigen test or culture of lower respiratory secretions using selective media; epidemiologic links to environmental sources can be confirmed when isolates from clinical and environmental specimens match by molecular typing (9). One species, Legionella pneumophila, accounts for approximately $90 \%$ of reported legionellosis cases in the United States (7).

Because Legionella transmission occurs from manmade environmental settings, the most effective strategy for prevention of Legionnaires' disease is through control of Legionella in water systems in buildings. In 2015, ASHRAE (formerly known as the American Society of Heating, Refrigerating, and Air-Conditioning Engineers) published a consensus standard for the primary prevention of Legionnaires' disease (10), which calls for the development and implementation of water management programs in large or complex water systems in buildings. The standard, which is based on best practices, focuses on identifying hazardous conditions and applying control measures to interrupt Legionella growth and transmission.

Outbreak investigations often find manmade water systems with maintenance gaps that permit the growth of Legionella.

\footnotetext{
${ }^{*}$ Large or complex water systems, where Legionella can grow and spread, are most often associated with commercial, institutional, multiunit residential, health care, and industrial buildings, often with multiple stories and complicated plumbing systems. Buildings in which vulnerable populations, such as immunocompromised or elderly persons, live or are treated are also considered to have complex water systems.
} 
To identify opportunities for prevention, summaries of all CDC field investigations of outbreaks of Legionnaires' disease during 2000-2014 were reviewed to characterize water system maintenance deficiencies leading to those outbreaks.

\section{Methods}

CDC offers assistance to health departments with field investigations of outbreaks of Legionnaires' disease. After each investigation, CDC reviews and summarizes the field notes to understand conditions that led to the outbreak. These summaries highlight the main findings from each investigation, including the numbers of cases and deaths, clinical or environmental strains of Legionella identified, potential or confirmed environmental sources, and possible environmental factors that contributed to the outbreak, as well as recommended solutions for the management of current outbreaks and prevention of future outbreaks.

CDC reviewed all investigation summaries and associated publications describing Legionnaires' disease outbreak investigations conducted during 2000-2014. Investigations involving cruise ships were excluded, because their water systems are managed differently from land-based water systems. Two investigators used a standard abstraction form to review the relevant materials. Confirmed and suspected Legionnaires' disease cases were defined using each outbreak's case definitions; thus, slight variations in case definition among outbreaks were possible. Investigation summaries were reviewed to identify possible root causes that could facilitate Legionella growth and transmission. Each reviewer independently assigned findings to one or more of four categories: 1) process failures, in which a process, such as a water management program, was missing or inadequate; 2) human errors, in which a person did not perform as expected, such as not replacing hot tub filters according to manufacturer's recommendations; 3) equipment failures, in which a piece of equipment did not operate as expected, such as a malfunctioning disinfectant delivery system; and 4) unmanaged external changes, in which adjustments were not made to account for events outside a building water system, such as nearby construction leading to changes in potable water quality. Discrepant categorizations were resolved through consultation with a third reviewer.

\section{Results}

During 2000-2014, CDC participated in 38 field investigations of Legionnaires' disease. Three investigations, determined not to be outbreaks because of lack of sufficient clinical or epidemiologic evidence, were excluded. Eight investigations involving cruise ships, associated with 19 confirmed and 17 suspected cases of Legionnaires' disease, including two deaths, were also excluded. Among the remaining 27 investigations,
24 occurred in U.S. states and territories, two in Mexico, and one in Canada. The most frequent outbreak settings were hotels and resorts $(\mathrm{n}=12,44 \%)$, long-term care facilities (5, 19\%), and hospitals (4, 15\%) (Table 1). The remaining six outbreaks were evenly distributed among senior living facilities $(\mathrm{n}=2,7 \%)$, workplaces $(2,7 \%)$, and the community $(2,7 \%)$. Potable water was the most frequent source of exposure $(\mathrm{n}=15,56 \%)$, followed by cooling towers $(6,22 \%)$, hot tubs $(2,7 \%)$, industrial equipment $(1,4 \%)$, and a decorative fountain $(1,4 \%)$; for two outbreaks $(7 \%)$, sources were not identified (Figure 2). Potable water sources accounted for $58 \%$ of travel-associated outbreaks (in hotels and resorts) and 67\% of health care-associated outbreaks (in hospitals and long-term care facilities).

All 27 outbreaks were caused by Legionella pneumophila serogroup 1. Among 13 (48\%) investigations (Table 1), links between human cases and water sources were established through DNA-sequence-based typing that identified indistinguishable clinical and environmental isolates. No clinical isolate was available for nine (33\%) outbreaks, no environmental isolate was available for one (4\%), and neither a clinical nor environmental isolate was available for two $(7 \%)$; the clinical and environmental isolates did not match for the remaining two $(7 \%)$ outbreaks. All available outbreak strains reacted with monoclonal antibody 2 of the international L. pneumophila serogroup 1 panel, a potential marker of increased virulence (11).

The 27 outbreaks included 415 cases, 323 (78\%) of which were confirmed ${ }^{\dagger}$ and $92(22 \%)$ suspected (Table 1). A median of 10 confirmed and suspected cases occurred in each outbreak (range $=3-82$ ). The median number of cases in cooling tower outbreaks was 22, and in potable water outbreaks was 10 . Health care-associated outbreaks accounted for $57 \%$ of all 415 cases, with a median of 19 cases per health care-associated outbreak; travel-associated outbreaks accounted for $25 \%$ of cases, with a median of seven cases per travel-associated outbreak.

Among confirmed and suspected Legionnaires' disease cases, 65 deaths occurred; the median outbreak case fatality rate was $7 \%$ (range $=0 \%-80 \%)$. Health care-associated outbreaks accounted for $85 \%$ of deaths (median health care-associated outbreak case fatality rate $=24 \%$, range $=6 \%-80 \%$ ); travel-associated outbreaks accounted for $6 \%$ of deaths (median travel-associated outbreak case fatality rate $=0 \%$, range $=0 \%-17 \%)$. Patients in seven of the nine health careassociated outbreaks included persons who were employees, visitors, or outpatients who did not stay overnight at the facility. No transplant patients were among the health care-associated cases. In 23 investigations for which the outbreak duration could be determined, the median interval from onset of the † For comparison, an estimated 41,500 cases of confirmed cases of Legionnaires'
disease were reported to CDC during 2000-2014 (unpublished data). 
TABLE 1. CDC field Investigations of Legionnaires' disease outbreaks — North America, 2000-2014* $(n=27)$

\begin{tabular}{|c|c|c|c|c|c|c|c|c|}
\hline \multirow{2}{*}{$\begin{array}{l}\text { Year of } \\
\text { investigation }\end{array}$} & \multirow[b]{2}{*}{ Setting } & \multirow[b]{2}{*}{ Source } & \multirow{2}{*}{$\begin{array}{l}\text { Environmental and } \\
\text { clinical isolate match }\end{array}$} & \multicolumn{3}{|c|}{ No. confirmed and suspected cases } & \multirow[b]{2}{*}{ No. deaths } & \multirow{2}{*}{$\begin{array}{l}\text { Case fatality } \\
\text { rate (\%) }\end{array}$} \\
\hline & & & & Total§ & Confirmed $\$$ & Suspected ${ }^{\S}$ & & \\
\hline 2001 & Workplace & Industrial equipment & No & 4 & 4 & 0 & 2 & 50 \\
\hline 2001 & Hotel/Resort & Potable water & Yes & 21 & 5 & 16 & 1 & 5 \\
\hline 2002 & $\begin{array}{l}\text { Long-term care } \\
\text { facility }\end{array}$ & Potable water & Yes & 31 & 12 & 19 & 2 & 6 \\
\hline 2003 & Hotel/Resort & Potable water & No clinical isolate & 3 & 3 & 0 & 0 & 0 \\
\hline 2004 & Hotel/Resort & Potable water & No clinical isolate & 8 & 7 & 1 & 0 & 0 \\
\hline 2004 & Hotel/Resort & Hot tub & $\begin{array}{l}\text { No environmental } \\
\text { or clinical isolate }\end{array}$ & 6 & 5 & 1 & 0 & 0 \\
\hline 2004 & Community & Cooling tower & No clinical isolate & 9 & 7 & 2 & 2 & 22 \\
\hline 2005 & Community & Decorative fountain & Yes & 18 & 18 & 0 & 1 & 6 \\
\hline 2005 & $\begin{array}{l}\text { Long-term care } \\
\text { facility }\end{array}$ & Cooling tower & Yes & 82 & 82 & 0 & 23 & 28 \\
\hline 2006 & Hospital & Potable water & Yes & 10 & 10 & 0 & 3 & 30 \\
\hline 2006 & Senior living facility & Potable water & No clinical isolate & 6 & 3 & 3 & 0 & 0 \\
\hline 2008 & Hotel/Resort & Potable water & Yes & 13 & 11 & 2 & 0 & 0 \\
\hline 2009 & Senior living facility & Potable water & Yes & 10 & 10 & 0 & 1 & 10 \\
\hline 2010 & Hotel/Resort & Potable water & Yes & 11 & 10 & 1 & 0 & 0 \\
\hline 2010 & Hotel/Resort & Cooling tower & Yes & 8 & 6 & 2 & 1 & 13 \\
\hline 2010 & Workplace & Cooling tower & Yes & 29 & 7 & 22 & 0 & 0 \\
\hline 2011 & Hospital & Potable water & No clinical isolate & 13 & 3 & 10 & 1 & 8 \\
\hline 2011 & Hotel/Resort & Unknown? & $\begin{array}{l}\text { No environmental } \\
\text { or clinical isolate }\end{array}$ & 3 & 3 & 0 & 0 & 0 \\
\hline 2011 & $\begin{array}{l}\text { Long-term care } \\
\text { facility }\end{array}$ & Potable water & No clinical isolate & 10 & 4 & 6 & 8 & 80 \\
\hline 2011 & Hotel/Resort & Potable water & No clinical isolate & 5 & 5 & 0 & 0 & 0 \\
\hline 2012 & Hospital & $\begin{array}{l}\text { Potable water } \\
\text { (possibly also } \\
\text { decorative fountain) }\end{array}$ & Yes & 21 & 21 & 0 & 5 & 24 \\
\hline 2013 & $\begin{array}{l}\text { Long-term care } \\
\text { facility }\end{array}$ & Unknown & No & 19 & 15 & 4 & 5 & 26 \\
\hline 2013 & Hotel/Resort & Cooling tower & No clinical isolate & 15 & 15 & 0 & 1 & 7 \\
\hline 2013 & $\begin{array}{l}\text { Long-term care } \\
\text { facility }\end{array}$ & Cooling tower & Yes & 41 & 39 & 2 & 6 & 15 \\
\hline 2013 & Hotel/Resort & Hot tub & $\begin{array}{l}\text { No environmental } \\
\text { isolate }\end{array}$ & 4 & 3 & 1 & 0 & 0 \\
\hline 2014 & Hotel/Resort & $\begin{array}{l}\text { Potable water } \\
\text { (and possibly } \\
\text { hot tub) }\end{array}$ & No clinical isolate & 6 & 6 & 0 & 1 & 17 \\
\hline 2014 & Hospital & Potable water & Yes & 9 & 9 & 0 & 2 & 22 \\
\hline Total & & & & 415 & 323 & 92 & 65 & $7 * *$ \\
\hline
\end{tabular}

* Excludes one pseudo-outbreak, two non-outbreaks, and eight cruise ship outbreaks.

+ On the basis of DNA-sequence-based typing.

$\S$ For the purposes of this analysis, cases of confirmed and suspect Legionnaires' disease were defined using each outbreak's case definition.

" Decorative fountain suspected; potable water/hot tub not excluded.

** Median.

first to last cases was 49 days. Median outbreak duration was longer for potable water outbreaks (98 days) than for outbreaks linked to other sources (28 days).

Twenty-three (85\%) investigation summaries had sufficient information to evaluate the contribution of deficiencies in water system maintenance to the outbreak (Table 2). The most frequent deficiencies noted were categorized as process failures ( $\mathrm{n}=15,65 \%)$, followed by human errors $(12,52 \%)$, equipment failures $(8,35 \%)$, and unmanaged external changes $(8,35 \%)$. For 11 (48\%) outbreaks, deficiencies in more than one category were reported. Sixteen (70\%) investigations reported inadequate water disinfectant levels and $12(52 \%)$ reported water temperatures in the optimal range for Legionella growth (12). ${ }^{\S}$ Indications of inadequate maintenance of hot tubs and decorative fountains were almost always noted. Among the seven investigations where outbreaks were believed to be associated with unmanaged external changes, nearby construction $(\mathrm{n}=3,43 \%)$ and problems with water mains $(3,43 \%)$ were most frequently noted. Three buildings had water management programs (all developed before the

\footnotetext{
${ }^{\$}$ Although Legionella has been recovered from water with temperatures outside this range, the temperature range most favorable for growth of Legionella is $25^{\circ} \mathrm{C}-42^{\circ} \mathrm{C}\left(77^{\circ} \mathrm{F}-108^{\circ} \mathrm{F}\right)$. For health care facilities, ASHRAE Guideline $12-2000$ recommends storing and distributing cold water at temperatures $<20^{\circ} \mathrm{C}$ $\left(<68^{\circ} \mathrm{F}\right)$, whereas hot water should be stored at $>60^{\circ} \mathrm{C}\left(>140^{\circ} \mathrm{F}\right)$ and circulated with a minimum return temperature of $51^{\circ} \mathrm{C}\left(124^{\circ} \mathrm{F}\right)$. In other settings, hot water should be stored at $\geq 49^{\circ} \mathrm{C}\left(\geq 120^{\circ} \mathrm{F}\right)$.
} 
publication of ASHRAE's standard in 2015); however, the occurrence of outbreaks suggests that the existing water management programs were inadequate $(13,14)$.

\section{Conclusions and Comments}

The number of cases of Legionnaires' disease in the United States is increasing, and associated mortality is substantial. Identifying ways to reduce environmental transmission of Legionella is crucial to reducing morbidity and mortality associated with Legionnaires' disease. The new ASHRAE standard establishes minimum requirements for management of the risk for Legionella growth and transmission in building water systems. Gaps in maintenance that could be addressed with a water management program to prevent Legionnaires' disease outbreaks were described in $23(85 \%)$ of 27 investigated outbreaks. Outbreaks resulted from a combination of deficiencies, most frequently classified as process failures and human errors. In the majority of outbreaks, inadequate water disinfectant levels and temperatures in the optimal range for Legionella growth were observed; implementing a functional water management program could address these deficiencies through routine monitoring of disinfectant levels and water temperature (10). Deficiencies related to equipment failures and unmanaged external changes were less common but are also remediable through preventive measures, such as flushing of potable water systems after water main breaks. Although approximately half the outbreaks included in this analysis resulted from multiple deficiencies, approximately half resulted from a single deficiency, suggesting that even a single deficiency can be sufficient to cause an outbreak; thus, all deficiencies should be addressed.

The most frequent outbreak settings in this analysis were hotels and resorts, long-term care facilities, and hospitals. Although $44 \%$ of the outbreaks were travel-associated and 33\% were health care-associated, health care-associated outbreaks were larger and resulted in more deaths than travel-associated outbreaks. Potable water was the most frequent source of exposure; however, outbreaks related to cooling tower outbreaks were associated with larger numbers of cases. This finding is consistent with the outdoor location of cooling towers and their ability to create plumes of potentially contaminated water that can expose larger numbers of persons than potable water outbreaks. Potable water outbreaks are usually associated with cases among building occupants, such as hospital patients and hotel guests. Hot tubs have been reported to be an important cause of outbreaks in hotels and cruise ships (15). Regardless of setting or source, a comprehensive approach to prevention requires an understanding of the mechanisms by which Legionella growth and transmission can occur in any building water system. Understanding the nature of deficiencies in water system maintenance using a categorization scheme such as the one described in this report can help inform plans for remediation and prevention following outbreaks of Legionnaires' disease.

Until published by ASHRAE in 2015, consensus recommendations regarding the development of water management programs to reduce transmission of Legionella were unavailable; thus, ASHRAE's approach to developing and implementing Legionella water management programs for water systems in buildings might be unfamiliar to building owners and managers (10). CDC and its partners have developed a toolkit (http:// www.cdc.gov/legionella/WMPtoolkit) to facilitate implementation of this new standard. The multistep process begins by determining if a building is at increased risk for growth and transmission of Legionella, in which case the formation of a specialized management team is required. The toolkit guides the team through the process of identifying and controlling conditions that can permit Legionella growth and transmission in their building water systems. The process requires careful planning, frequent communication, consistent implementation, and regular review. Taking these steps should reduce the risk for Legionella growth and transmission. 
TABLE 2. Deficiencies in water system maintenance contributing to growth and transmission of Legionella among outbreaks of Legionnaires' disease investigated by CDC - North America, 2000-2014 $(n=23)$

\begin{tabular}{|c|c|c|c|c|c|c|}
\hline \multirow[b]{2}{*}{ Setting } & \multirow[b]{2}{*}{ Source } & \multirow[b]{2}{*}{ Deficiency } & \multicolumn{4}{|c|}{ Category* } \\
\hline & & & $\begin{array}{l}\text { Process } \\
\text { failure }\end{array}$ & $\begin{array}{c}\text { Human } \\
\text { error }\end{array}$ & $\begin{array}{l}\text { Equipment } \\
\text { failure }\end{array}$ & $\begin{array}{l}\text { Unmanaged } \\
\text { external change }\end{array}$ \\
\hline Hotel/Resort & Potable water & $\begin{array}{l}\text { Temperatures in optimal range for Legionella growth }{ }^{\dagger} \text { in cold } \\
\text { potable water }\end{array}$ & $\checkmark$ & & & \\
\hline Hotel/Resort & Potable water & $\begin{array}{l}\text { Temperatures in optimal range for Legionella growth }{ }^{\dagger} \text { in } \\
\text { potable water } \\
\text { Inadequate disinfectant in potable water }\end{array}$ & $\checkmark$ & & & \\
\hline Hotel/Resort & Potable water & $\begin{array}{l}\text { Temperatures in optimal range for Legionella growth }{ }^{\dagger} \text { in } \\
\text { potable water } \\
\text { Inadequate disinfectant in potable water }\end{array}$ & $\checkmark$ & & & \\
\hline Hotel/Resort & Potable water & $\begin{array}{l}\text { Temperatures in optimal range for Legionella growth }{ }^{\dagger} \text { in hot } \\
\text { water heaters and in potable water } \\
\text { Inadequate disinfectant in potable water, including water } \\
\text { coming from supplier } \\
\text { Stagnation } \$ \text { because of large amounts of water storage and } \\
\text { closed wing with unused potable water system (because of } \\
\text { low occupancy) }\end{array}$ & $\checkmark$ & & & \\
\hline Hotel/Resort & Potable water & $\begin{array}{l}\text { Temperatures in optimal range for Legionella growth }{ }^{\dagger} \text { in both } \\
\text { hot and cold potable water } \\
\text { Inadequate disinfectant in potable water } \\
\text { Water temperature in hot water heater lower than indicated on } \\
\text { thermostat }\end{array}$ & $\checkmark$ & & $\checkmark$ & \\
\hline Hotel/Resort & Potable water & $\begin{array}{l}\text { Temperatures in optimal range for Legionella growth }{ }^{\dagger} \text { in } \\
\text { potable water } \\
\text { Legionella water management program (in place as a result of } \\
\text { previous outbreak) not comprehensive (i.e., disinfectant not } \\
\text { monitored, and remediation performed on a room-by-room } \\
\text { basis at certain action thresholds only) } \\
\text { Inadequate disinfectant in potable water because of } \\
\text { installation of chlorine dioxide injector before the hot water } \\
\text { heaters, and occasional mechanical failures of the disinfectant } \\
\text { pumps }\end{array}$ & $\checkmark$ & $\checkmark$ & $\checkmark$ & \\
\hline Hotel/Resort & $\begin{array}{l}\text { Potable water } \\
\text { (and possibly } \\
\text { also hot tub) }\end{array}$ & $\begin{array}{l}\text { Temperatures in optimal range for Legionella growth }{ }^{\dagger} \text { in } \\
\text { potable water } \\
\text { Lack of disinfectant in potable water (resort served by well } \\
\text { water, disinfectant not required by state law) } \\
\text { Lack of potable water distribution mapping plans (staff unable } \\
\text { to describe system) } \\
\text { Poor access to filters and disinfectant feeder because of hot tub } \\
\text { placement and equipment design } \\
\text { Broken water main (not followed by appropriate flushing of } \\
\text { the distribution system) }\end{array}$ & $\checkmark$ & $\checkmark$ & $\checkmark$ & $\checkmark$ \\
\hline Hotel/Resort & Hot tub & $\begin{array}{l}\text { Inadequate maintenance of hot tub } \\
\text { Lack of knowledge by contracted pool operator }\end{array}$ & & $\checkmark$ & & \\
\hline Hotel/Resort & Hot tub & $\begin{array}{l}\text { Inadequate disinfectant in hot tub water because of inaccurate } \\
\text { disinfectant feeding equipment, resulting in inadequate } \\
\text { disinfectant delivery (unrecognized by hot tub operator) } \\
\text { Inadequate hot tub maintenance and disinfectant monitoring } \\
\text { Unenforced limits on bather loads } \\
\text { Improper air circulation because of dysfunctional exhaust vents } \\
\text { of dehumidifier in pool room, leading to increased exposure } \\
\text { to aerosolized bacteria }\end{array}$ & & $\checkmark$ & $\checkmark$ & \\
\hline Hotel/Resort & Cooling tower & $\begin{array}{l}\text { Inadequate disinfectant in cooling tower because of irregular } \\
\text { addition of disinfectant by contractor } \\
\text { Inadequate record keeping }\end{array}$ & & $\checkmark$ & & \\
\hline
\end{tabular}

See table footnotes on page 583 . 
TABLE 2. (Continued) Deficiencies in water system maintenance contributing to growth and transmission of Legionella among outbreaks of Legionnaires' disease investigated by CDC - North America, 2000-2014 ( $n=23)$

\begin{tabular}{|c|c|c|c|c|c|c|}
\hline \multirow[b]{2}{*}{ Setting } & \multirow[b]{2}{*}{ Source } & \multirow[b]{2}{*}{ Deficiency } & \multicolumn{4}{|c|}{ Category* } \\
\hline & & & $\begin{array}{l}\text { Process } \\
\text { failure }\end{array}$ & $\begin{array}{l}\text { Human } \\
\text { error }\end{array}$ & $\begin{array}{l}\text { Equipment } \\
\text { failure }\end{array}$ & $\begin{array}{c}\text { Unmanaged } \\
\text { external change }\end{array}$ \\
\hline Hotel/Resort & $\begin{array}{l}\text { Unknown } \\
\text { (suspected to } \\
\text { be a decorative } \\
\text { fountain, but } \\
\text { possibly } \\
\text { potable water } \\
\text { or hot tub) }\end{array}$ & $\begin{array}{l}\text { Temperatures in optimal range for Legionella growth }{ }^{\dagger} \text { in } \\
\text { potable water } \\
\text { Inadequate disinfectant in potable water and hot tubs } \\
\text { Disinfectant not routinely added to decorative fountain, } \\
\text { inadequate maintenance of decorative fountain suspected } \\
\text { (but fountain was hyperchlorinated before testing) }\end{array}$ & $\checkmark$ & $\checkmark$ & & \\
\hline Hospital & Potable water & $\begin{array}{l}\text { Hospital under major construction** at time of outbreak } \\
\text { (Legionella found in potable water almost exclusively in new } \\
\text { building) }\end{array}$ & & & & $\checkmark$ \\
\hline Hospital & Potable water & $\begin{array}{l}\text { Temperatures in optimal range for Legionella growth }{ }^{\dagger} \text { at hot } \\
\text { water storage tank } \\
\text { Inadequate disinfectant in potable water } \\
\text { Use of tap water in personal respiratory device } \\
\text { Insufficient clinical testing for Legionella among patients with } \\
\text { pneumonia meeting criteria for possible Legionnaires' disease }\end{array}$ & $\checkmark$ & $\checkmark$ & & \\
\hline Hospital & Potable water & $\begin{array}{l}\text { Existing Legionella risk-reduction plan inadequate (Legionella } \\
\text { consistently found in hospital potable water) } \\
\text { Inadequate disinfectant in potable water (documented by } \\
\text { hospital and not addressed) } \\
\text { Insufficient clinical testing for Legionella among patients with } \\
\text { health care-associated pneumonia } \\
\text { Failure of hospital to implement water restrictions upon } \\
\text { detecting contamination with Legionella in potable water and } \\
\text { associated cases of Legionnaires' disease } \\
\text { Failure of hospital to notify public health officials of a } \\
\text { recognized outbreak of Legionnaires' disease } \\
\text { Stagnation } \$ \text { following plumbing inspection and flushing } 2 \\
\text { months before occupation of new hematology-oncology unit }\end{array}$ & $\checkmark$ & $\checkmark$ & & $\checkmark$ \\
\hline Hospital & $\begin{array}{l}\text { Potable water } \\
\text { (and possibly } \\
\text { also decorative } \\
\text { fountain) }\end{array}$ & $\begin{array}{l}\text { Inadequate chlorine in potable water } \\
\text { Legionella water management program not comprehensive } \\
\text { (i.e., testing for disinfectant and pH in potable water not } \\
\text { required) } \\
\text { Failure to recognize cases of Legionnaires' disease as being } \\
\text { health care-associated } \\
\text { Delayed reaction to contamination of potable water with } \\
\text { Legionella because of } \\
\text { 1) Unrecognized contamination (decreased sensitivity of } \\
\text { samples because of small volume) } \\
\text { 2) Reliance upon action threshold to prompt remediation } \\
\text { (when health care-associated cases occurred below } \\
\text { threshold) } \\
\text { Failure of copper-silver ionization system to control Legionella } \\
\text { colonization in hospital } \\
\text { Extensive construction** at hospital } \\
\text { Lack of start-up and shutdown procedure for decorative } \\
\text { fountains } \\
\text { Disinfectant not added to decorative fountain }\end{array}$ & $\checkmark$ & $\checkmark$ & $\checkmark$ & $\checkmark$ \\
\hline $\begin{array}{l}\text { Long-term care } \\
\text { facility }\end{array}$ & Potable water & $\begin{array}{l}\text { Temperatures in optimal range for Legionella growth }{ }^{\dagger} \text { in hot } \\
\text { potable water (because of anti-scalding regulations) } \\
\text { Thermostatic mixing valves placed nearer to hot water heater } \\
\text { than to faucet, creating long lengths of piping with } \\
\text { temperatures in optimal range for Legionella growth } \\
\text { Inadequate disinfectant in potable water }\end{array}$ & $\checkmark$ & & & \\
\hline $\begin{array}{l}\text { Long-term care } \\
\text { facility }\end{array}$ & Potable water & Inadequate disinfectant in potable water & $\checkmark$ & & & \\
\hline $\begin{array}{l}\text { Long-term care } \\
\text { facility }\end{array}$ & Cooling tower & $\begin{array}{l}\text { Inadequate disinfectant in cooling tower because of timed } \\
\text { delivery that did not allow disinfectant to be delivered when } \\
\text { cooling tower was not running }\end{array}$ & & & $\checkmark$ & \\
\hline
\end{tabular}


TABLE 2. (Continued) Deficiencies in water system maintenance contributing to growth and transmission of Legionella among outbreaks of Legionnaires' disease investigated by CDC - North America, 2000-2014 ( $n=23)$

\begin{tabular}{|c|c|c|c|c|c|c|}
\hline \multirow[b]{2}{*}{ Setting } & \multirow[b]{2}{*}{ Source } & \multirow[b]{2}{*}{ Deficiency } & \multicolumn{4}{|c|}{ Category* } \\
\hline & & & $\begin{array}{l}\text { Process } \\
\text { failure }\end{array}$ & $\begin{array}{l}\text { Human } \\
\text { error }\end{array}$ & $\begin{array}{l}\text { Equipment } \\
\text { failure }\end{array}$ & $\begin{array}{l}\text { Unmanaged } \\
\text { external change }\end{array}$ \\
\hline $\begin{array}{l}\text { Senior living } \\
\text { facility }\end{array}$ & Potable water & $\begin{array}{l}\text { Temperatures in optimal range for Legionella growth }{ }^{\dagger} \text { in hot } \\
\text { potable water because of reduction of hot water heater from } \\
\text { original temperature set by the building's contractors } \\
\text { Excessive sediment in potable water system because of new } \\
\text { construction** } \\
\text { Broken water main d during construction** }\end{array}$ & & $\checkmark$ & & $\checkmark$ \\
\hline $\begin{array}{l}\text { Senior living } \\
\text { facility }\end{array}$ & Potable water & $\begin{array}{l}\text { Temperatures in optimal range for Legionella growth }{ }^{\dagger} \text { in hot } \\
\text { potable water } \\
\text { Inadequate disinfectant in potable water } \\
\text { Failure to follow manufacturer's recommendations for periodic } \\
\text { draining of hot water heaters to remove sediment } \\
\text { Water temperature in hot water heater lower than indicated on } \\
\text { thermostat } \\
\text { Maintenance of water main } \\
\text { and water outage }\end{array}$ & $\checkmark$ & $\checkmark$ & $\checkmark$ & $\checkmark$ \\
\hline Community & Cooling tower & $\begin{array}{l}\text { Tropical storm with heavy rain and flooding immediately } \\
\text { before symptom onset of first case }{ }^{t+}\end{array}$ & & & & $\checkmark$ \\
\hline Community & $\begin{array}{l}\text { Decorative } \\
\text { fountain }\end{array}$ & Inadequate maintenance of decorative fountain & & $\checkmark$ & & \\
\hline Workplace & Cooling tower & $\begin{array}{l}\text { Lack of start-up and shutdown procedures for cooling tower } \\
\text { Lack of staff training on operation and maintenance of } \\
\text { cooling tower } \\
\text { Cooling tower dysfunction, prompting opening of windows } \\
\text { Heavy rainfall, high humidity, and warm temperatures } \\
\text { preceded onset of cases }{ }^{\dagger+}\end{array}$ & $\checkmark$ & & $\checkmark$ & $\checkmark$ \\
\hline Total & & & 15 & 12 & 8 & 8 \\
\hline
\end{tabular}

\footnotetext{
* Each reviewer independently assigned findings to one or more of four categories: 1) process failures, in which a process, such as a water management program, was missing or is inadequate; 2) human errors, in which a person did not perform as expected (e.g., not replacing hot tub filters according to manufacturer's recommendations); 3) equipment failures, in which a piece of equipment did not operate as expected (e.g., a malfunctioning disinfectant delivery system); and 4) unmanaged external changes, in which adjustments were not made to account for events outside a building water system (e.g., nearby construction leading to changes in potable water quality).

+ Although recovery of Legionella from water with temperatures outside this range have occurred, the temperature range most favorable for growth of Legionella is $25^{\circ} \mathrm{C}-42^{\circ} \mathrm{C}\left(77^{\circ} \mathrm{F}-108^{\circ} \mathrm{F}\right)$. For health care facilities, ASHRAE Guideline $12-2000$ recommends storing and distributing cold water at $<20^{\circ} \mathrm{C}\left(68^{\circ} \mathrm{F}\right)$, whereas hot water should be stored at $>60^{\circ} \mathrm{C}\left(140^{\circ} \mathrm{F}\right)$ and circulated with a minimum return temperature of $51^{\circ} \mathrm{C}\left(124^{\circ} \mathrm{F}\right)$. In other settings, hot water should be stored at $\geq 40^{\circ} \mathrm{C}\left(\geq 120^{\circ} \mathrm{F}\right)$.

$\S$ Water stagnation encourages biofilm growth, reduces temperature, and reduces levels of disinfectant.

" Broken water mains lead to changes in water pressure which can dislodge biofilm (thereby freeing Legionella into water entering the building) and can introduce particulate matter into water entering the building (which can consume disinfectant).

** Vibrations and changes in water pressure experienced during construction can dislodge biofilm and free Legionella into the water entering the building.

${ }^{+\dagger}$ Investigators suspect inadequate maintenance of cooling towers (with inadequate disinfectant) a heavy rain.
}

The findings in this report are subject to at least three limitations. First, the scope of legionellosis encompasses Legionnaires' disease and Pontiac fever. Because fatality is only associated with Legionnaires' disease, prevention messages are generally targeted toward preventing Legionnaires' disease and not Pontiac fever; therefore, the Pontiac fever cases in the five outbreaks reporting Pontiac fever (range $=1-101$ cases) were excluded. Second, although understanding the clinical aspects of Legionnaires' disease is an essential step in addressing the increasing number of reported cases, these aspects have been reported elsewhere $(6,16)$ and are not discussed here. Finally, this analysis might not capture all possible gaps in maintenance for several reasons. CDC typically completes investigation summaries within a few weeks of an investigation and investigators might not have had access to environmental information that might have become available later. In addition, CDC does not participate in all investigations of outbreaks of Legionnaires' disease; thus, these findings might not represent all root causes associated with outbreaks. Moreover, the outbreak-associated deficiencies described in this report might not represent root causes associated with sporadic Legionnaires' disease cases.

Missed prevention opportunities can lead to outbreaks of Legionnaires' disease. Making water management programs a routine part of building ownership and management will require education and reinforcement. Environmental and public health professionals can help by incorporating the ASHRAE standard into licensing and accreditation requirements, modifying building and public health codes to include 
water management programs, and providing tools and information to help local building owners and managers implement water management programs. Future studies should evaluate the implementation and effectiveness of water management programs in buildings with large or complex water systems. Widespread use of such programs might reduce the growth and transmission of Legionella, which, in addition to early diagnosis with appropriate clinical testing, might reduce the number and size of Legionnaires' disease outbreaks and help reduce the occurrence of Legionnaires' disease in the United States.

\footnotetext{
${ }^{1}$ Division of Bacterial Diseases, National Center for Immunization and Respiratory Diseases, CDC; ${ }^{2}$ Division of Emergency and Environmental Health Services, National Center for Environmental Health, CDC.
}

Corresponding author: Laura A. Cooley, LCooley@cdc.gov, 404-639-2096.

\section{References}

1. Adams D, Fullerton K, Jajosky R, et al. Summary of notifiable infectious diseases and conditions-United States, 2013. MMWR Morb Mortal Wkly Rep 2015;62:1-122. http://dx.doi.org/10.15585/mmwr. mm6253a1

2. CDC. Notice to readers: final 2014 reports of nationally notifiable infectious diseases. MMWR Morb Mortal Wkly Rep 2015;64:1019-33. http://dx.doi.org/10.15585/mmwr.mm6436a8

3. Dooling KL, Toews KA, Hicks LA, et al. Active bacterial core surveillance for legionellosis-United States, 2011-2013. MMWR Morb Mortal Wkly Rep 2015;64:1190-3. http://dx.doi.org/10.15585/mmwr.mm6442a2

4. Beer KD, Gargano JW, Roberts VA, et al. Surveillance for waterborne disease outbreaks associated with drinking water-United States, 20112012. MMWR Morb Mortal Wkly Rep 2015;64:842-8. http://dx.doi. org/10.15585/mmwr.mm6431a2

5. CDC. Waterborne disease and outbreak surveillance system. Atlanta, GA: US Department of Health and Human Services, CDC; 2016. http:// www.cdc.gov/healthywater/surveillance/surveillance-reports.html
6. Hicks LA, Garrison LE, Nelson GE, et al. Legionellosis-United States, 2000-2009. MMWR Morb Mortal Wkly Rep 2011;60:1083-6.

7. Fields BS, Benson RF, Besser RE. Legionella and Legionnaires' disease: 25 years of investigation. Clin Microbiol Rev 2002;15:506-26. http:// dx.doi.org/10.1128/CMR.15.3.506-526.2002

8. Correia AM, Ferreira JS, Borges V, et al. Probable person-to-person transmission of Legionnaires' disease. N Engl J Med 2016;374:497-8. http://dx.doi.org/10.1056/NEJMc1505356

9. Mercante JW, Winchell JM. Current and emerging Legionella diagnostics for laboratory and outbreak investigations. Clin Microbiol Rev 2015;28:95-133. http://dx.doi.org/10.1128/CMR.00029-14

10. ASHRAE. Legionellosis: risk management for building water systems. ANSI/ASHRAE Standard 188-2015. Atlanta, GA: ASHRAE; 2015. http://www.mesc.org/downloads/v/PCTI/ASHRAE\%20188\%20-\%20 2015\%20FINAL.pdf

11. Kozak NA, Benson RF, Brown E, et al. Distribution of lag-1 alleles and sequence-based types among Legionella pneumophila serogroup 1 clinical and environmental isolates in the United States. J Clin Microbiol 2009;47:2525-35. http://dx.doi.org/10.1128/JCM.02410-08

12. ASHRAE. Minimizing the risk of legionellosis associated with building water systems. ASHRAE guideline 12-2000. Atlanta, GA: ASHRAE; 2000. http://legionella.org/publications/non-visible/ ashrae-guideline-12-2000/

13. Demirjian A, Lucas CE, Garrison LE, et al. The importance of clinical surveillance in detecting Legionnaires' disease outbreaks: a large outbreak in a hospital with a Legionella disinfection system-Pennsylvania, 20112012. Clin Infect Dis 2015;60:1596-602. http://dx.doi.org/10.1093/ $\mathrm{cid} / \mathrm{civ} 153$

14. Silk BJ, Moore MR, Bergtholdt M, et al. Eight years of Legionnaires' disease transmission in travellers to a condominium complex in Las Vegas, Nevada. Epidemiol Infect 2012;140:1993-2002. http:// dx.doi.org/10.1017/S0950268811002779

15. CDC. Cruise-ship — associated Legionnaires disease, November 2003 May 2004. MMWR Morb Mortal Wkly Rep 2005;54:1153-5.

16. Phin N, Parry-Ford F, Harrison T, et al. Epidemiology and clinical management of Legionnaires' disease. Lancet Infect Dis 2014;14:101121. http://dx.doi.org/10.1016/S1473-3099(14)70713-3 